\title{
ATHYSANUS ARGENTATUS FABR. IN NEW ENGLAND. (HOMOPTERA)
}

\author{
By NaTHAN BANKS \\ Holliston, Mass.
}

Soon after moving to Holliston over twenty years ago I found in my backyard (part of the abandoned "fox-hole" of a glacier) numerous specimens of a large leaf-hopper, and every year since I have taken specimens. It was not in the Hemiptera of Connecticut, nor in Osborn's papers on the Maine and New York Jassidae. Six or eight years ago, being in Washington I spoke to Mr. Oman about it, and he thought it might be a species he had taken the year before near Mt. Washington. Specimens sent him he identified as a European species, Athysanus argentatus Fabr., the type of the genus. It occurs where the grass is dense and chiefly near the beginning of the swamp, not in pastures, orchards, or gardens where the economic entomologist would have taken it long ago.

In a trip across Maine from the White Mountains to Bangor I found it in the Pinkham Notch, and at various places in Maine, rather abundant near the Belgrade Lakes. Mr. Moore of Quebec, has shown me a specimen from Peakes Island, Maine, and recently I have seen a few specimens from the Plymouth area of Massachusetts.

It is a pale species, and when fresh the folded wings are silvery white as far each side as the first brown streak in the cells, except that the commissure, claval suture, and first claval vein are brown. There are three brown streaks through the cells and a short one in the fork of medius. The costa is convex, thickened and usually ivory-white. The wing is rather slender, no angle at end of claval suture, so that the brown of the commissure continues straight out and around tip to end of medius; the three apical cross-veins are near each other, there is no second cross-vein. On the head there is a curved black line from eye to eye, the vertex extending somewhat in front of it, more so in middle than elsewhere. The frons shows eight or nine transverse slightly curved lines of pale brown or 
dark gray each side. There is usually a black mark at base of antenna, and another just above it. The pronotum on hind part is finely, transversely striate; there is a brown line each side, not reaching front, and a short line in front of wing-base. The scutellum has three dark lines, usually visible beneath the pronotum. The abdomen has three black streaks, above and beneath, the median one with irregular edges, the lateral ones situate before margin.

The hind tibiae have a black streak with adjoining dots below; the mid and front femora have a brown line above and another shorter just below it on the front.

This insect is one of several spiders and insects found in my swamp, or near it, that are holarctic; two of the spiders like Athysanus, had not been known from Massachusetts until found here by Mr. Emerton and myself, and like the Athysanus occur in swampy places in North Europe. These forms following the retreat of the glacier became trapped in certain pockets where conditions were favorable for them. All of these forms are mature in early summer, while the several southern forms that I find here are mature only in late summer. 

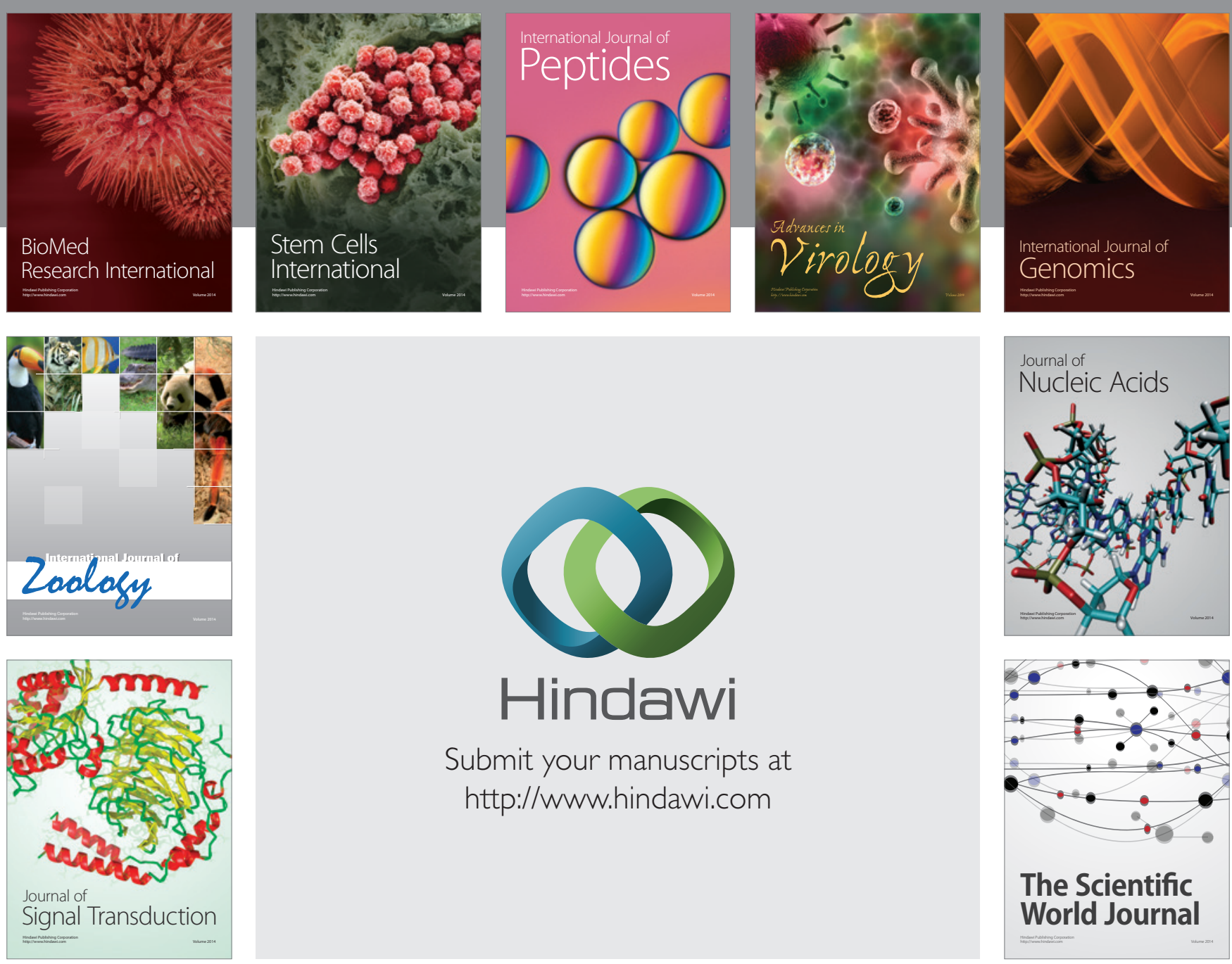

Submit your manuscripts at

http://www.hindawi.com
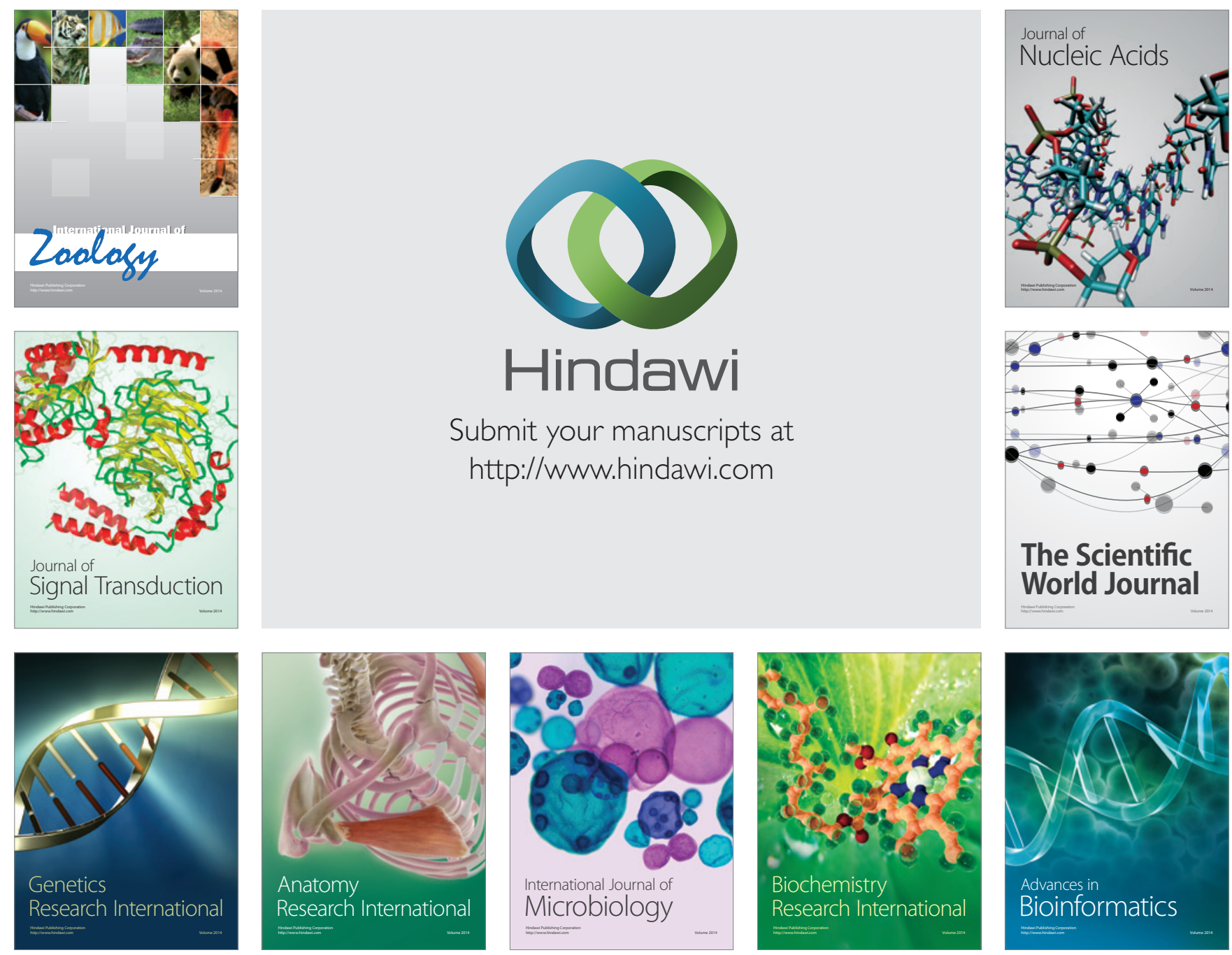

The Scientific World Journal
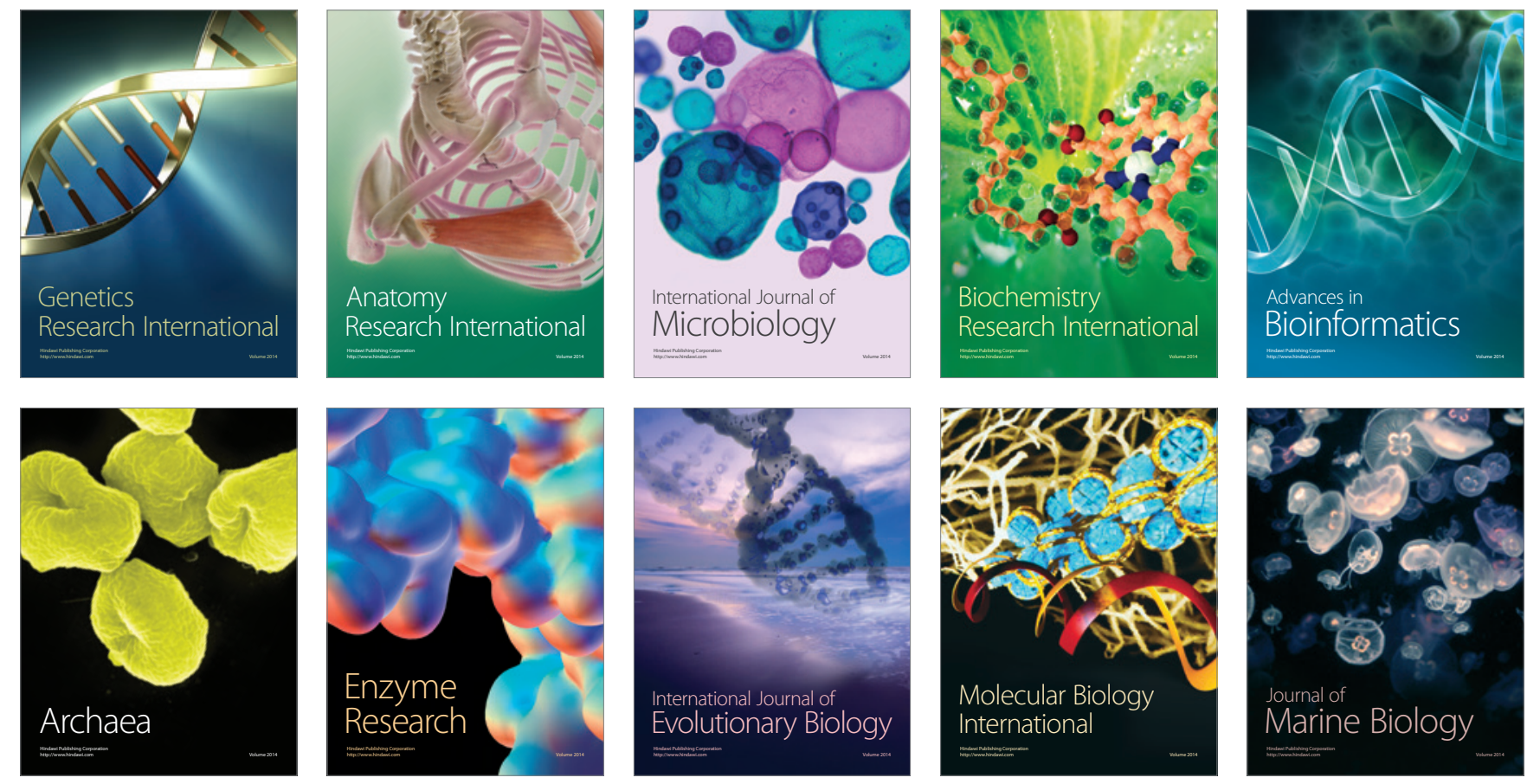